\title{
ANALISIS TINGKAT KEPENTINGAN DESAIN INDUSTRI PRODUK HANDPHONE: STUDI KASUS DI FAKULTAS EKONOMI UBINUS
}

\author{
Dyah Budiastuti ${ }^{1}$; Diananda GF $^{2}$
}

\begin{abstract}
ABSTRACK
Article present the importance of industrial design on handphone product that today it becomes one of most popular communication tools. The research used qualitative descriptive method on handphone product that most likely used by Faculty of Economics students of Bina Nusantara University. The research result shows that the role of industrial design in handphone product development has higher interest in fulfilling the ergonomic needs compare to the role in fulfilling the aesthetic needs.
\end{abstract}

Keywords: handphone, industry design, ergonomic need, aesthetical need

\section{ABSTRAK}

Artikel menjelaskan pentingnya desain industri pada produk handphone yang saat ini berfungsi sebagai salah satu alat komunikasi paling populer. Penelitian menggunakan metode deskriptif kualitataif terhadap produk handphone yang paling banyak dipakai oleh mahasiswa Fakultas Ekonomi UBiNus. Hasil penelitian menunjukkan bahwa peran desain industri dalam pengembangan produk handphone memiliki tingkat kepentingan yang lebih tinggi dalam memenuhi kebutuhan ergonomik dibandingkan perannya dalam memenuhi kebutuhan estetis.

Kata kunci: telepon genggam, desain industri,kebutuhan ergonomik, kebutuhan estetis

\footnotetext{
${ }^{1}$ Staf Pengajar Fakultas Ekonomi Jurusan Manajemen, UBiNus, Jakarta

${ }^{2}$ Mahasiswa Fakultas Ekonomi Jurusan Manajemen, UBiNus, Jakarta
} 


\section{PENDAHULUAN}

Perhimpunan Desainer Industri Amerika (IDSA) mendefinisikan desain industri sebagai "jasa profesioanal dalam menciptakan dan mengembangkan konsep dan spesifikasi guna mengoptimalkan fungsi, nilai, dan penampilan produk, serta sistem untuk mencapai keuntungan yang mutual antara pemakai dan produsen”. Kenyataannya, desainer industri memfokuskan diri pada bentuk dan interaksi pemakai produk.

Dreyfuss (1967) membuat daftar lima tujuan penting desain industri dalam mengembangkan produk baru. Pertama, kegunaan: Hasil produksi manusia harus selalu aman, mudah digunakan, dan intuitif. Setiap ciri harus dibentuk sedemikian rupa sehingga memudahkan pemakainya mengetahui fungsinya. Kedua, penampilan: Bentuk, garis, proporsi, dan warna digunakan untuk menyatukan produk menjadi satu produk yang menyenangkan. Ketiga, kemudahan pemeliharaan: Produk harus juga didesain untuk memberitahukan bagaimana mereka dapat dirawat dan diperbaiki. Keempat, biaya rendah: Bentuk dan ciri memegang peranan besar dalam biaya peralatan dan produksi. Oleh karena itu, hal ini harus diperhatikan secara bersama-sama oleh tim. Kelima, komunikasi: Desain produk harus dapat mewakili filosofi desain perusahaan dan misi perusahaan melalui visualisasi kulitas produk.

Untuk menilai pentingnya desain industri terhadap suatu produk, perlu dilihat dari dua dimensi, yaitu kebutuhan ergonomik dan kebutuhan estetis.

\section{Kebutuhan Ergonomik}

Kebutuhan ergonomik desain industri terdiri dari berikut ini. Pertama, seberapa penting kemudahan pemakaian? Kemudahan pemakaian mungkin sangat penting untuk produk yang sering digunakan dan produk yang jarang digunakan. Kemudahan pemakaian akan lebih diperlukan jika produk mempunyai beberapa ciri atau cara mengoperasikannya yang mungkin membingungkan dan menyebabkan frustasi pemakainya. Ketika kemudahan pemakaian menjadi kriteria yang penting, desainer industri perlu menjamin bahwa ciri-ciri produk secara efektif dapat memberitahukan fungsinya.

Kedua, seberapa pentingnya kemudahan perawatan? Jika produk perlu diperbaiki secara berkala, kemudahan perawatan menjadi penting. Jadi, penting bahwa ciri-ciri suatu produk adalah untuk memberitahukan prosedur perawatan/perbaikan kepada pemakainya.

Ketiga, berapa banyak interaksi pemakai yang diperlukan untuk fungsi produk? Secara umum, semakin banyak interaksi pemakai dengan produk, produk akan semakin tergantung pada desain industri dan setiap interaksi mungkin membutuhkan suatu pendekatan desain yang berbeda dan atau riset tambahan. 
Keempat, berapa pembaruan yang interaksi pemakai perlukan? Suatu antarmuka pemakai memerlukan perbaikan terhadap desain yang telah ada yang secara relatif akan mudah dipahami untuk didesain. Semakin banyak pembaruan pada interfase pemakai, mungkin memerlukan riset yang substansial dan studi kemungkinan. Kelima, Apa pokok permasalahan keamanan? Semua produk mempunyai pertimbangan keamanan. Untuk beberapa produk, hal ini dapat menghasilkan tantangan yang nyata bagi tim desain.

\section{Kebutuhan Estetis}

Kebutuhan estetis dari desain industri terdiri dari hal berikut. Pertama, apakah diferensiasi produk visual diperlukan? Produk dengan market dan teknologi yang stabil sangat tergantung pada desain industri untuk menciptakan daya tarik estetis dan tentunya diferensiasi visual.

Kedua, seberapa penting gengsi kepemilikan, kesan, dan mode? Persepsi pelanggan terhadap suatu produk sebagian didasarkan oleh daya tarik estetis. Produk yang menarik mungkin diasosiasikan dengan mode dan kesan yang tinggi. Pada akhirnya, hal itu akan menciptakan perasaan gengsi yang tinggi pada pemiliknya. Hal itu mungkin berlawanan dengan suatu produk yang terlihat dan terasa kasar atau konservatif.

Ktiga, akankah suatu produk estetis memotivasi tim? Suatu produk yang mempunyai daya tarik estetis dapat membangkitkan perasaan bangga diantara para staf desain dan manufaktur. Kebanggaan tim dapat memotivasi dan menyatukan setiap orang yang berhubungan dengan proyek. Konsep awal desain industri memberikan tim suatu visi konkrit terhadap hasil akhir usaha pengembangan.

Untuk menilai tingkat kepentingan desain industri dari suatu produk, dapat dilakukan dengan memperhatikan beberapa dimensi berikut. Pertama, Kebutuhan Ergonomik: Kemudahan pemakaian; Kemudahan perawatan; Kuantitas interaksi pemakai; Pembaruan interaksi pemakai; Keamanan; Kenyamanan. Kedua, Kebutuhan Estetis: Diferensiasi produk; Gengsi kepemilikan, mode atau kesan; Motivasi tim

\section{PEMBAHASAN}

Penilaian tingkat kepentingan produk handphone ini dilakukan terhadap merk dan tipe handphone yang paling banyak digunakan oleh mahasiswa Fakultas Ekonomi UbiNus. Penelitian menggunakan metode deskriptif kualitatif dengan teknik pengumpulan data kuesioner.

Fakultas Ekonomi UBiNus memiliki 2 (dua) program studi, yaitu Manajemen dan Akuntansi dengan sebaran jumlah mahasiswa sebagai berikut. 
Tabel 1 Jumlah MPahasiswa Fakultas Ekonomi UBiNus

\begin{tabular}{ccc}
\hline TAHUN ANGKATAN & $\begin{array}{c}\text { MANAJEMEN } \\
\text { (Mhs) }\end{array}$ & $\begin{array}{c}\text { AKUNTANSI } \\
\text { (Mhs) }\end{array}$ \\
\hline 1998 & 15 & 1 \\
1999 & 85 & 19 \\
2000 & 76 & 28 \\
2001 & 691 & 184 \\
2002 & 3333 & 1482 \\
2003 & 2774 & 1100 \\
2004 & 2814 & 1194 \\
2005 & 3437 & 1872 \\
\hline Jumlah & 13225 & 5880 \\
\hline Total Mahasiswa (Manajemen + Akuntansi) & 19105 \\
\hline
\end{tabular}

Sumber: LRI UBiNus

Dengan prosedur sampling cluster random sampling dan ukuran sampling secara proposional dengan tingkat kesalahan $10 \%$, didapatkan responden terpilih untuk program studi Manajemen sebanyak 69 mahasiswa dan program studi akuntansi sebanyak 31 mahasiswa.

Hasil penelitian menunjukkan terdapat lima merek handphone yang digunakan mahasiswa Fakultas Ekonomi, yaitu Nokia, Sony Ericson, Motorolla, Samsung, dan Siemens. Diantara kelima merek tersebut, Nokia adalah handpone yang paling banyak (79\%) digunakan mahasiswa. Dari handphone Nokia ini, ditemukan 32 tipe/seri yang berbeda yang umumnya digunakan, dan paling banyak memilih tipe/seri 6600 (12.67\%).

Didasarkan pada pemilihan merek dan tipe/seri handphone yang paling banyak digunakan mahasiswa Fakultas Ekonomi itulah, penilaian tingkat kepentingan desain industri terhadap produk handphone ini dilakukan. Dari 79 mahasiswa yang menggunakan handphone merek nokia, berdasarkan kebutuhan ergonomik dan estetis diperoleh informasi berikut. Berdasarkan Kebutuhan Ergonomik. Pertama, dilihat dari dimensi kemudahan pemakaian dan diharapkan handphone sangat penting sebagai telepon yang dapat dibawa kemanapun. Mungkin sering digunakan secara berkala, diperlukan untuk situasi darurat, dan dapat dioperasikan oleh pengemudi mobil ketika menyetir, 31,65\% mahasiswa menganggap kemudahan pemakaian handphone adalah cukup penting (3.42).

Kedua, sebagai produk elektronik yang integrated, 32.91\% mahasiswa menganggap kemudahan perawatan handphone cukup penting (2.77) bagi pengembangan desain industrinya. Ketiga, kuantitas interaksi pemakai, seperti mengganti baterai, charge baterai, dialing, ketik pesan singkat (SMS), menerima panggilan, membuka flip (tutup) handphone dianggap kurang penting (2.37) oleh mahasiswa (39,24\%). 
Keempat, perbaikan pada handphone untuk mempermudah interaksi pemakai dengan handphone, seperti keypad (tombol dan susunannya), membuka casing handphone, mengganti baterai dan sim card, membuka keypad yang sliding, flip pada handphone sebagai bagian dari pembaruan interaksi pemakai, oleh 34,18\% mahasiswa dianggap cukup penting (2.58).

Kelima, sebanyak 31,65\% mahasiswa menganggap kurang penting (2.30) sejumlah perlengkapan dan aksesori HP yang didesain untuk keamanan, seperti earphone bagi pengendara mobil, atau desain antena, dan sudut handphone agar tidak membahayakan.

Keenam, bentuk sejumlah perlengkapan dan aksesori handphone perlu didesain untuk kenyamanan, seperti kenyamanan saat menggenggam handphone atau saat memasukkan handphone ke dalam saku, kenyamanan saat berbicara/mendengarkan panggilan di handphone (letak speaker/microphone-nya), sebanyak 36,71\% menanggap kenyamanan dalam menggunakan handphone adalah cukup penting (3.42).

Dari hasil tersebut, dapat dijelaskan bahwa mahasiswa fakultas Ekonomi UbiNus menganggap peran desain industri untuk produk handphone dalam memenuhi kebutuhan ergonomik adalah cukup penting $(2,81)$.

Berdasarkan Kebutuhan Estetis, diperoleh informasi berikut. Pertama, ratusan merk dan model handphone di pasaran, tampilannya (fitur, teknologi, ukuran/dimensi, desain, pilihan warna, bahan, bentuk), oleh 26,58\% mahasiswa dianggap penting (3.63) untuk membedakannya dari handphone merek/tipe lain. Kedua, sebanyak 53,26\% mahasiswa mengangap kurang penting (1.98) handphone secara fisik harus terlihat menarik, seperti pilihan warna, desain bentuk, ukuran/dimensi.

Ketiga, Handphone harus memberikan kesan/imej yang baik, menarik ketika dilihat atau dipegang, dan menciptakan imej yang sesuai dengan harapan pemakai, sebanyak 49,37 \% mahasiswa menganggap kurang penting (2.0). Keempat, Handpone sebagai produk yang terlihat bergengsi untuk penggunanya pada saat digunakan sebagai alat komunikasi perorangan pada area publik atau tempat umum sehingga memberikan prestise tersendiri kepada pemakainya, bagi 51,90\% mahasiswa dianggap tidak penting (1.72).

Hasil itu menunjukkan bahwa mahasiswa fakultas Ekonomi UbiNus menganggap peran desain industri pada produk handphone dalam memenuhi kebutuhan estetis adalah kurang penting (2.33). Secara keseluruhan, mahasiswa fakultas Ekonomi UbiNus menganggap bahwa peran desain industri sebuah produk handphone memiliki tingkat kepentingan yang lebih tinggi dalam memenuhi kebutuhan ergonomik dibandingkan perannya dalam memenuhi kebutuhan estetis dan diferensiasi produk dan kemudahan pemakaian merupakan hal yang perlu mendapat perhatian lebih. 


\section{PENUTUP}

Simpulan yang diperoleh berdasarkan penelitian sebagai berikut. Pertama, merek dan seri handphone yang paling banyak digunakan oleh mahasiswa fakultas Ekonomi UBiNus adalah Nokia seri 6600. Kedua, peran desain industri dalam memenuhi kebutuhan ergonomik pada produk handphone nokia oleh mahasiswa fakultas Ekonomi UbiNus dianggap cukup penting. Ketiga, peran desain industri dalam memenuhi kebutuhan estetis pada produk handphone nokia oleh mahasiswa fakultas Ekonomi UbiNus dianggap kurang penting. Keempat, diferensiasi produk dan kemudahan pemakaian dari handphone nokia memiliki tingkat kepentingan yang tinggi dalam pengembangan produk handphone. Kelima, menurut mahasiswa fakultas Ekonomi UbiNus, desain industri mempunyai peran yang cukup penting dalam pengembangan produk handphone.

\section{DAFTAR PUSTAKA}

Adjie, Haryo. 2005. "Laporan khusus; Yang Flop di Pasaran.” Diakses Januari 2005.http://www.selular.co.id/lapsus/0112/05.htm.

Nuryadi, Andra. 2003. "Sejarah Telepon Seluler; Dulu Dijinjing, Sekarang Digenggam.” Diakses 10 Desember 2005 dari http://www.kompas.com/kompascetak/0310/03/muda/598953.htm,

Rosgani. 2004. “Teknologi ponsel; Mengulang sejarah PC?” Diakses 10 Desember 2005 dari http://www.angelfire.com/blog/mobileart/arsip/040620.html

Satriyantono, Toni. 2001. “Tantangan Aplikasi Wireless Generasi 3 (3G).” Diakses 10 Desember 2005 dari http://satriyantono.net/works/paper1.htm.

Saudi, Adhi. 2004. “Kolom; Fashion atau Function?” Diakses Agustus 2004 dari http://www.selular.co.id/kolom/0814/04.htm

Ullrich, Karl T. and Steven D. Eppinger. 2001. Perancangan dan Pengembangan Produk. Edisi Pertama. Jakarta: Salemba Teknika. 